\author{
KARINA KRZCIUK \\ Zakład Geochemii i Ochrony Środowiska \\ Instytut Chemii \\ Uniwersytet Jana Kochanowskiego w Kielcach \\ Świętokrzyska 15G, 25-406 Kielce \\ E-mail: karina.krzciuk@ujk.edu.pl
}

\title{
FITOGÓRNICTWO PIERWIASTKÓW ZIEM RZADKICH JAKO METODA ZRÓWNOWAŻONEGO GOSPODAROWANIA NIEODNAWIALNYMI ZASOBAMI ZIEMI
}

\section{WSTEP}

Górnictwo konwencjonalne stanowi duże wyzwanie, zarówno ekonomiczne, jak i środowiskowe. Komercyjne wydobycie rud powinno być przede wszystkim opłacalne, dlatego odbywa się najczęściej na terenach silnie wzbogaconych $\mathrm{w}$ pozyskiwane pierwiastki. Obszary te występuja rzadko i sa charakterystyczne jedynie dla lokalnych środowisk. $Z$ drugiej strony, w obliczu szybkiego rozwoju cywilizacyjnego, zapotrzebowanie na metale i niemetale wciąż wzrasta, szczególnie na te wykorzystywane $w$ nowoczesnych technologiach. Ponieważ surowce mineralne stanowia nieodnawialne zasoby Ziemi, coraz większą uwagę poświęca się ich zarówno racjonalnemu wykorzystaniu, jak i planowaniu oraz przestrzeganiu zasad zrównoważonego rozwoju podczas wydobycia. Wzrasta również popularność technologii pozyskiwania pierwiastków opartych na nowoczesnych metodach biotechnologicznych. Działania takie umożliwiają ekstrakcję metali $z$ rud średnio wzbogaconych lub występujacych $\mathrm{w}$ formie rozproszonej, a także umożliwiaja remediacje terenów zanieczyszczonych na skutek działań górniczych (SHEORAN i współaut. 2009). Wśród flory występujaccej endemicznie na tak trudnych do uprawy roślin terenach odkryto gatunki zdolne do ponadprzeciętnej, znacznie przekraczajacej typowa, akumulacji pierwiastków śladowych, w tym pierwiastków ziem rzadkich. Rośliny te nazwano hiperakumulatorami (JAFFRÉ i współaut. 1976, BROOKS i współaut. 1977). Hiperakumula- tory zdolne sa do ekstrakcji pierwiastków $z$ gleby, a po okresie wzrostu i zbioru oraz spaleniu, ich biomasa stanowi tak zwana biorude (ang. bio-ore), która w procesie fitogórnictwa wykorzystuje się do odzyskiwania pierwiastków o znaczeniu ekonomicznym (GAEUSZKA 2005). Metoda ta może stanowić ,zielona”, przyjazna środowisku alternatywę dla górnictwa konwencjonalnego.

Pierwiastki ziem rzadkich (lantanowce; ang. rare earth elements, REE) to grupa metali $z$ liczba atomowa od 57 (La-lantan) do 71 (Lu-lutet). Gospodarcze znaczenie lantanowców wiaże się $z$ ich szerokim stosowaniem w przemyśle (głównie przemysł High-Tech), medycynie, a także $\mathrm{w}$ rolnictwie (PETROSINO i współaut. 2013, ZHANG i współaut. 2013). Od lat 50. ubiegłego wieku ich wydobycie stale wzrasta, co ma obecnie wpływ na zwiększony udział $\mathrm{w}$ środowisku pierwiastków ziem rzadkich pochodzenia antropogenicznego. REE nie sa pierwiastkami niezbędnymi dla roślin (THOMAS i współaut. 2014). W niektórych przypadkach może ujawniać się ich toksyczność ze względu na podobieństwo ich jonów do jonów wapnia (BROwN i współaut. 1990). Generalnie, toksyczność REE w stosunku do roślin jest niska. Rozpowszechnienie pierwiastków ziem rzadkich w Europie związane jest głównie $z$ ich pochodzeniem geogenicznym, nie stwierdzono tu (w dużej skali) ani historycznych, ani współczesnych źródeł antropogenicznych REE (FEDELE i współaut. 2008). W Europie najwyższe zawartości lantanowców w formacjach litych występuja 
we Włoszech i w regionie Fennoskandynawii (Petrosino i współaut. 2013). Największe pokłady REE znajduja się w Chinach, które dostarczaja na rynek swiatowy ok. 95\% tych pierwiastków (COOK i współaut. 2013). Choć toksyczność pierwiastków ziem rzadkich dla człowieka nie jest tak wysoka, jak np. kadmu czy ołowiu, to długotrwała ekspozycja na REE może powodować obniżenie IQ u dzieci (ZHU i współaut. 1996), zmiany w układach: krażenia, immunologicznym, nerwowym (ZHANG 2000). Dlatego zainteresowanie ta grupa pierwiastków nie ogranicza się do ich pozyskiwania, ważnym aspektem jest tu również oczyszczanie środowiska (remediacja).

Niniejszy artykuł stanowi ocenę procesu fitogórnictwa w kontekście zrównoważonego gospodarowania zasobami naturalnymi poprzez wskazanie plusów, minusów oraz perspektyw prezentowanej metody w pozyskiwaniu pierwiastków ziem rzadkich.

\section{ROŚLINY (HIPER)AKUMULUJĄCE}

Rośliny przystosowane do wzrostu i rozwoju na terenach wzbogaconych $\mathrm{w}$ pierwiastki śladowe nazywa się metalofitami, a wśród nich wyróżnia się hiperakumulatory, gdy stężenia pierwiastków w nadziemnych częściach roślin przekraczają ustalone wartości progowe, podane kolejno: $100 \mathrm{mg} \cdot \mathrm{kg}^{-1}$ suchej masy (SM) dla Se, Cd i Tl, $300 \mathrm{mg} \cdot \mathrm{kg}^{-1} \mathrm{SM}$ dla Cu, Co, Cr; $1000 \mathrm{mg} \cdot \mathrm{kg}^{-1} \mathrm{SM}$ dla Ni i Pb; 3000 $\mathrm{mg} \cdot \mathrm{kg}^{-1} \mathrm{SM}$ dla Zn oraz $10000 \mathrm{mg} \cdot \mathrm{kg}^{-1} \mathrm{SM}$ dla Mn (VAN DER ENT i współaut. 2013). Dla sumy pierwiastków ziem rzadkich ustalono wartość graniczna wynoszacca $1000 \mathrm{mg} \cdot \mathrm{kg}^{-1}$ SM. Większość roślin hiperakumulujących posiada również współczynnik bioakumulacji (ang. bioaccumulation factor, BF; jako stosunek ilości pierwiastka $\mathrm{w}$ nadziemnych częściach rośliny do jego ilości w glebie) większy od 1 (WANG i współaut. 2012). Hiperakumulatory sa zdolne do akumulacji nawet 1001000 krotnie wyższych stężeń pierwiastków w warunkach naturalnych (REEVES 1992), w porównaniu do roślin nie będących akumulatorami. Blisko 90\% hiperakumulatorów o wysokim potencjale wykorzystania w fitogórnictwie stanowia gatunki endemiczne dla gleb serpentynitowych, wystepujących m.in. w Portugalii, na Bałkanach, w Turcji, Iranie, Nowej Kaledonii, Indonezji, na Filipinach, w Australii, na Kubie, czy w centralnej Brazylii (KRZCIUK i GAŁUSZKA 2015). Obecnie znanych i opisanych jest ok. 500 gatunków hiperakumulatorów, choć liczba ta stale wzrasta. Około 80\% $z$ nich stanowia hiperakumulatory niklu (VAN DER ENT i współaut. 2013), znanych jest też ok. 20 gatunków roślin hiperakumulujacych REE. Przykładowe ilości REE w roślinach hiperakumulujacych te pierwiastki (w $\mathrm{mg} \cdot \mathrm{kg}^{-1} \mathrm{SM}$ ) sa następujące: Carya cathayensis - od 3 do 2296; Dicranopteris dicthotoma - 3358; Pronephrium simplex - 1234 (LIU i współaut. 2018). Przykładowe gatunki hiperakumulatorów REE to m.in. rośliny $z$ gatunku Asplenium, Carya, Pronephrium (OZAKI i współaut. 2000, XUE 2009, THOMAS 2011). Sam proces hiperakumulacji wśród roślin jest swego rodzaju fenomenem i nie jest to zjawisko do końca poznane. Roślina przeznaczona do procesu fitogórnictwa powinna odznaczać się następującymi cechami: (a) szybko rosnąć, (b) produkować duża ilość biomasy, (c) mieć dobrze rozwinięty system korzeniowy, (d) mieć zdolność akumulacji dużej ilości pierwiastków śladowych, (e) mieć zdolność efektywnego transportu pierwiastków $z$ korzeni do pędów, (f) wykazywać tolerancję $\mathrm{w}$ stosunku do zakumulowanych pierwiastków, (g) móc szybko przystosowywać się do różnych warunków klimatycznych, (h) być odporna na patogeny i szkodniki, (i) być łatwa w uprawie i zbiorze, (j) powinna mieć również wykształcone mechanizmy odstraszające roślinożerców, tak aby zapobiec wprowadzaniu toksyn do łańcucha pokarmowego (ALI i współaut. 2013). W idealnym przypadku, roślina posiada wszystkie wyżej wymienione cechy, jednak najczęściej dobór hiperakumulatorów do fitogórnictwa wiąze się $z$ pewnymi kompromisami. Częstym rozwiazaniem jest wybór roślin do fitoekstrakcji charakteryzujacych się mniejsza zdolnością do akumulacji pierwiastka, a większym przyrostem biomasy; dobrym rozwiazaniem jest wspomaganie akumulacji przez dodatek do gleby odpowiednich związkow chemicznych (patrz Metody zwiększajace efektywność ekstrakcji metali z gleby).

\section{POZYSKIWANIE METALI METODA FITOGÓRNICTWA}

Fitoekstrakcja znalazła zastosowanie nie tylko w fitoremediacji, polegajacej na remediacji wód, gleb z zanieczyszczeń, ale też $\mathrm{w}$ fitogórnictwie, polegającym na odzyskiwaniu pierwiastków o wartości ekonomicznej. Proces fitogórnictwa został przedstawiony na Ryc. 1. Pierwszym etapem procesu jest wytypowanie miejsca wzbogaconego $\mathrm{w}$ dany pierwiastek lub pierwiastki. Moga to być gleby naturalnie wzbogacone $\mathrm{w}$ wybrane pierwiastki, czy też gleby zanieczyszczone, jak np. składowiska odpadów pogórniczych, miejsca o wzmożonej działalności przemysłowej. Kolejnymi etapami są: dobór odpowiedniej rośliny i ewentualne wspomaganie wzrostu roślin i ułatwianie przyswajania przez nie pierwiastków przez dodatek nawozów, czy odpowiednich zwiąków chemicznych. Po zakończeniu wzrostu roślin następuje zbiór plonu i spalanie bioru- 


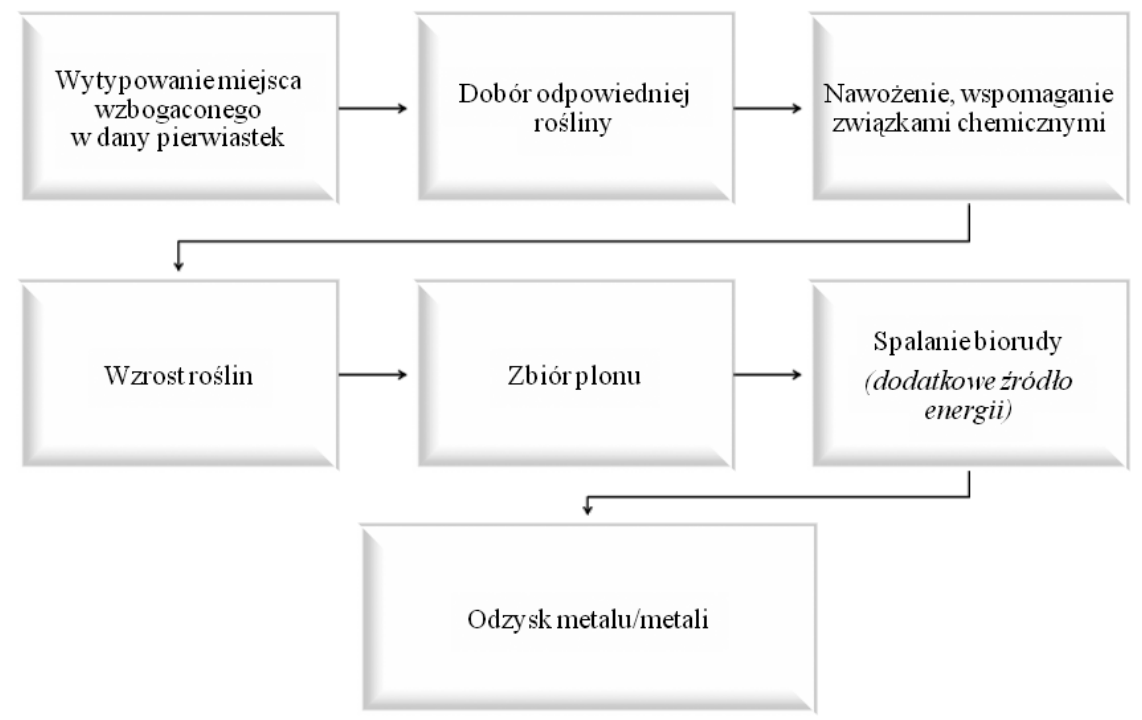

Ryc. 1. Schematyczne ujęcie najważniejszych etapów procesu fitogórnictwa.

dy w celu odzyskania pierwiastka $z$ biomasy. Sam proces spalania może stanowić dodatkowe źródło energii. Po etapie odzysku metali należy ponownie zbadać poziom zawartości pierwiastka w glebie, w celu sprawdzenia czy jest słuszne przeprowadzenie kolejnych serii upraw.

\section{METODY ZWIEKSZAJACE EFEKTYWNOSC EKSTRAKCJI METALI Z GLEBY}

Wydajność fitogórnictwa zależy nie tylko od właściwych cech roślin, ale również od formy występowania metali i niemetali w glebie. Jedynie część pierwiastków jest dostępna dla roślin (biodostępna). Efektywność fitogórnictwa może zatem zostać poprawiona nie tylko przez wpływ na czynniki zwiazane $z$ roślinami, ale także przez zwiększenie mobilności pierwiastków, czyli zmodyfikowanie czynników powiązanych z glebą (LASAT 2002) (Ryc. 2).

Pierwiastki pochodzenia naturalnego maja $z$ reguły dużo niższa biodostępność, niż te pochodzące ze źródel antropogenicznych (BOLAN i współaut. 2014). Na biodostępność pierwiastków w glebie wpływa szereg procesów fizyko-chemicznych decydujacych o rozpuszczalności ich związków.

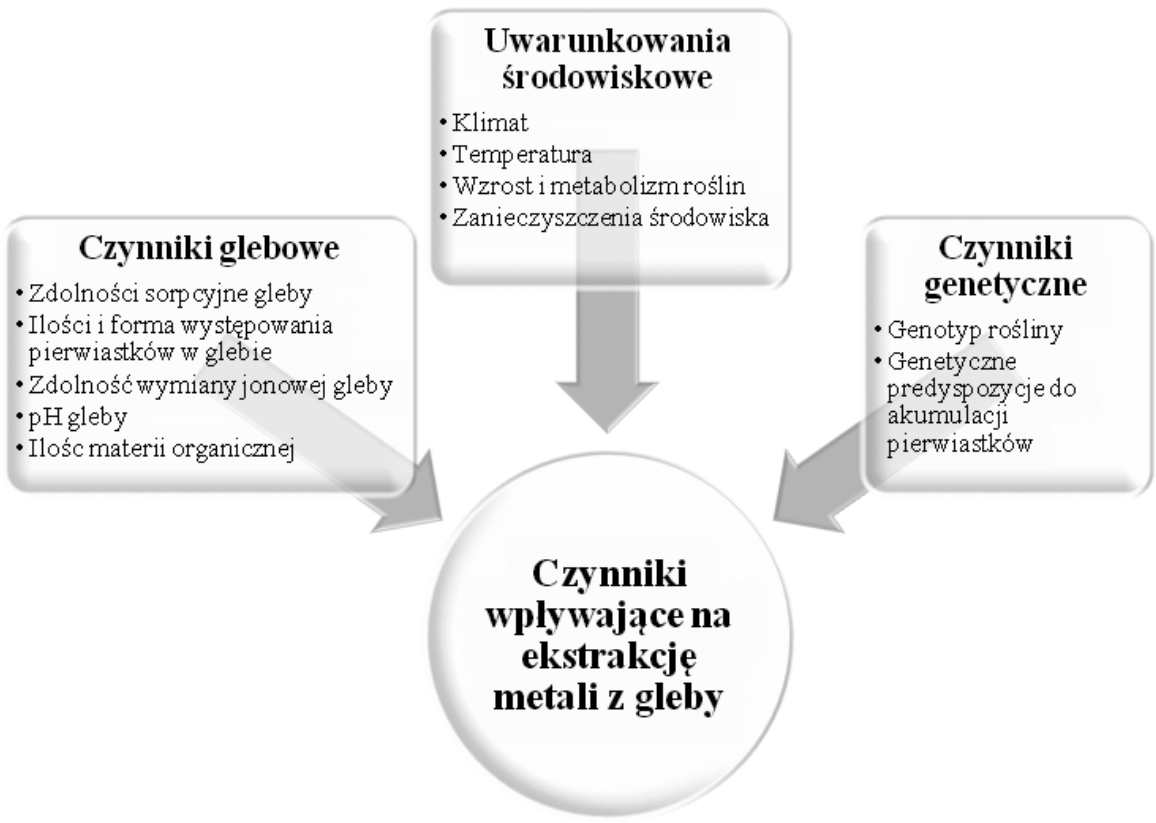

Ryc. 2. Najważniejsze czynniki wpływające na ekstrakcję metali z gleby (BHARGAVA i współaut. 2012). 


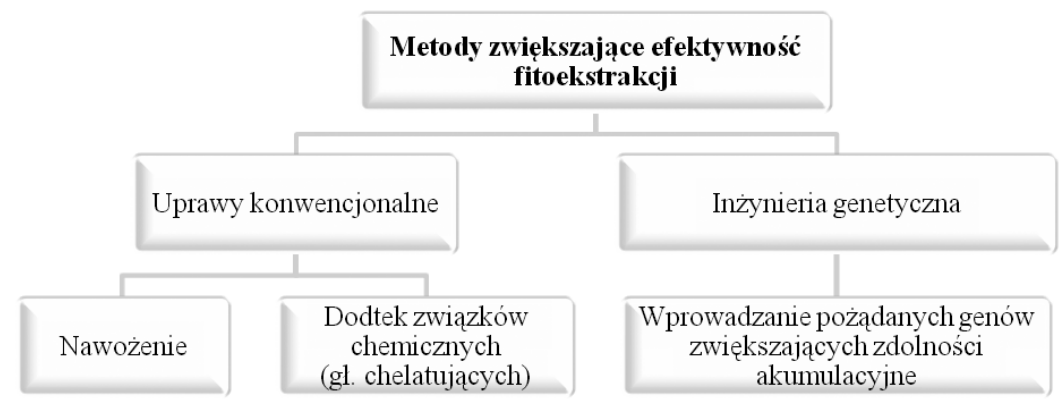

Ryc. 3. Metody wpływające na efektywność fitoekstrakcji.

Jednym $z$ ważniejszych aspektów fitogórnictwa jest zwiększenie zdolności akumulacyjnej roślin (Ryc. 3). Kluczowa rolę odgrywa również biomasa roślin. Dlatego prócz utrzymania optymalnego $\mathrm{pH}$ wpływajacego na biodostępność metali, ważne jest również nawożenie, które wspomaga prawidłowy rozwój i wzrost roślin (SHEORAN i współaut. 2009). Nawozy azotowe i potasowe dodawane do gleby powoduja obniżenie $\mathrm{pH}$, zwiększenie mobilności większości pierwiastków śladowych, a także lepszy wzrost roślin, gdyż w ich skład wchodza ważne pierwiastki biogenne. Ilość i jakość dodawanych nawozów powinna być dobierana $\mathrm{w}$ zależności od danego przypadku. Udowodniono, że dodatek takich substancji, prócz przyrostu biomasy roślin, pociaga za sobą zwiększona akumulację pierwiastków. Gleby o dużym potencjale wykorzystania w fitogórnictwie REE sa zwykle zubożone w cenne mikro- i makroelementy, jak magnez czy wapń. Dodatek nawozów powoduje nawet kilkakrotny wzrost biomasy roślin (SHEORAN i współaut. 2009).

Rośliny pobierają pierwiastki $z$ roztworu glebowego za pomoca korzeni (ryzosfera). Dlatego też naturalne hiperakumulatory zdolne sa do uwalniania zwiazków chelatujaccych (gł. fitochelaty) do ryzosfery. Dzięki temu, znacznie poprawia się biodostępność metali oraz ich transport do nadziemnych części roślin (EAPEN i D’Souza 2005). Fitochelaty sa to zwykle zwiazki organiczne o niskiej masie czasteczkowej, jak kwasy: jabłkowy, malonowy, szczawiowy, octowy, bursztynowy, czy też cukry i aminokwasy. Ponieważ hiperakumulatory zazwyczaj charakteryzuja się powolnym wzrostem i produkcja małej ilości biomasy, dlatego też szybkość procesu akumulacji pierwiastków jest znacznie ograniczona. Można ją jednak zwiększyć poprzez dodatek substancji chelatujacych (np. kwas cytrynowy, EDTA, DTPA) (SHEORAN i współaut. 2009). W ryzosferze obecne sa również mikroorganizmy, zarówno te żyjace wolno, jak i te pozostajace $\mathrm{w}$ symbiozie $\mathrm{z}$ roślinami (bakterie i grzyby). Wytwarzaja one zwiazki pomagajace w detoksykacji szkodliwych pierwiastków. Ich obecność może również zwiększyć biodostępność metali i wpłynać na efektywność ich pobierania (YANG i współaut. 2005). Wydajność przyswajania pierwiastków przez rośliny może zostać zwiększona także dzięki inżynierii genetycznej. W naturalnych warunkach rośliny hiperakumulujacce posiadaja dość mała biomasę, dlatego dobra alternatywą moga być rośliny transgeniczne (SHAH i NONGKYNRIH 2007). Jednym $z$ rozwiazań jest transmisja genów hiperakumulatora (tolerancja i detotyksyfikacja) do roślin nieakumulujacych (Clemens 2001).

\section{ASPEKT EKONOMICZNY FITOGORNICTWA}

Najpopularniejszym przykładem praktycznego wykorzystania fitogórnictwa jest użycie hiperakumulatora Alyssum murale do pozyskiwania niklu (ZHANG i współaut. 2014). Warunkiem wykorzystania procesu $\mathrm{w}$ praktyce jest cena ekstrahowanych $z$ gleby pierwiastków i ogólna opłacalność metody. Jedna $z$ roślin hiperakumulujących REE, majaca duży potencjał do ich fitoekstrakcji $z$ gleb, jest Dicranopteris dichotoma (LIU i współaut. 2018). W Tabeli 1 przedstawiono porównanie popularnych hiperakumulatorów wybranych pierwiastków śladowych $\mathrm{z} D$. dichotoma. Roślina ta charakteryzuje się stosunkowo duża produkcja biomasy, w porównaniu do innych gatunków hiperakumulatorów. Jej pędy zawieraja ok. 0,2\% REE, co w przeliczeniu na hektar uprawy daje możliwość pozyskania 230-240 kg REE (LIU i współaut. 2018). Przykładowe ceny pierwiastków należących do grupy lekkich pierwiastków ziem rzadkich (LREE) wynosza ok. 5418 USD/ tonę dla ceru, do 59084 USD/tonę dla neodymu, natomiast ceny pierwiastków należacych do grupy ciężkich pierwiastków ziem rzadkich (HREE) to: dysproz - 246 USD/ kg; terb -575 USD/kg (na podstawie http:// mineralprices.com; styczeń 2019). Po zbiorze roślin, kolejnym krokiem w pozyskiwaniu cennych metali jest spalanie biomasy i pro- 
Tabela 1. Rośliny o potencjale wykorzystania w fitogórnictwie i ceny ekstrahowanych metali (BROOKS i współaut. 1998).

\begin{tabular}{|c|c|c|c|c|c|c|}
\hline Metal & $\begin{array}{l}\text { Cena meta- } \\
\text { lu, USD } \mathrm{t}^{-1}\end{array}$ & Gatunek rośliny & $\begin{array}{l}\text { Biomasa } \\
\left(\mathrm{t} \cdot \mathrm{ha}^{-1} \cdot \mathrm{rok}^{-1}\right)\end{array}$ & $\begin{array}{l}\text { Ilość akumu- } \\
\text { lowanego pier- } \\
\text { wiastka } \\
\left(\mathrm{mg} \cdot \mathrm{kg}^{-1} \mathrm{SM}\right)\end{array}$ & $\begin{array}{l}\text { Definiowany za- } \\
\text { kres akumulacji } \\
\left(\mathrm{mg} \cdot \mathrm{kg}^{-1} \mathrm{SM}\right)^{*}\end{array}$ & $\begin{array}{l}\text { Zawartość } \\
\text { pierwiastka w } \\
\text { roślinach nie- } \\
\text { akumulujących } \\
\left(\mathrm{mg} \cdot \mathrm{kg}^{-1} \mathrm{SM}\right)\end{array}$ \\
\hline Cynk (Zn) & $2641^{a}$ & $\begin{array}{l}\text { Thlaspi calami- } \\
\text { nare }\end{array}$ & 4 & 10000 & 3000 & 100 \\
\hline Kadm (Cd) & $2739^{c}$ & $\begin{array}{l}\text { Thlaspi caerule- } \\
\text { scens }\end{array}$ & 4 & 3000 & 100 & 1 \\
\hline Kobalt (Co) & $36000^{\mathrm{b}}$ & $\begin{array}{l}\text { Haumaniastrum } \\
\text { robertii }\end{array}$ & 4 & 10200 & 300 & 1 \\
\hline Miedź (Cu) & $5925^{\mathrm{a}}$ & $\begin{array}{l}\text { Haumaniastrum } \\
\text { katangense }\end{array}$ & 5 & 8356 & 300 & 1 \\
\hline $\begin{array}{l}\text { Mangan } \\
(\mathrm{Mn})\end{array}$ & $1985^{c}$ & $\begin{array}{l}\text { Macadamia neuro- } \\
\text { phylla }\end{array}$ & 30 & 55000 & 10000 & 400 \\
\hline Nikiel (Ni) & $11780^{\mathrm{a}}$ & Berkheya coddii & 18 & 17000 & 1000 & 2 \\
\hline Ołów (Pb) & $2088^{a}$ & $\begin{array}{l}\text { Thlaspi rotundi- } \\
\text { folium }\end{array}$ & 4 & 8200 & 1000 & 5 \\
\hline$\Sigma \mathrm{REE}$ & $\begin{array}{l}5418- \\
1632972^{\mathrm{ci}}\end{array}$ & $\begin{array}{l}\text { Dicranopteris di- } \\
\text { chotoma }\end{array}$ & 15 & 2032 & 1000 & $1^{* *}$ \\
\hline
\end{tabular}

*wg Van Der Ent i współaut. 2013; **Markert 1992; a, średnia cena z ostatnich 3 miesięcy sprawdzana w styczniu 2019 wg portalu http://hutnictwo.wnp.pl/notowania/metale/; b, cena sprawdzana w styczniu 2019 wg portalu http://lme.com/; c, cena sprawdzana w styczniu 2019 wg portalu http://mineralprices.com; i, zakres cen dla pierwiastków ziem rzadkich (ceny od $5418 \mathrm{USD} \cdot \mathrm{t}^{-1}$ dla Ce do $1632972 \mathrm{USD} \cdot \mathrm{t}^{-1}$ dla Gd)

dukcja biorudy, co doprowadza do pozbycia się części organicznej i wzbogacenia pozyskiwanych pierwiastków. Nastepnie wykonuje się ługowanie, w którym parametry procesu dobiera się w zależności od ilości Si i Al w tkankach roślin. Popioły zawieraja około 1,6\% wagowego REE. Średni odzysk REE $z$ popiołu D. dichotomia wynosi 93\%. Jednak spopielone części roślin zawierają dużą część fazy amorficznej, przez co efektywne ługowanie może okazać się niemożliwe (LAUBIE i współaut. 2016). Obecnie trwaja prace nad rozwinięciem różnych metod ekstrakcji REE $z$ materiału roślinnego, jak np. bezpośrednia ekstrakcja za pomoca EDTA (LAUBIE i współaut. 2016).

\section{PODSUMOWANIE I PERSPEKTYWY}

Jedna $z$ największych zalet fitogórnictwa jest możliwość pozyskiwania cennych metali, w tym pierwiastków ziem rzadkich $z$ rud rozproszonych, gleb średnio wzbogaconych, czy $z$ miejsc o dużym zanieczyszczeniu pierwiastkami o znaczeniu gospodarczym. Kolejna, niewątpliwa zaleta procesu jest możliwość jednoczesnego oczyszczania gleb $z$ potencjalnie toksycznych pierwiastków (fitoremediacja), a także możliwość pozyskiwania ener- gii ze spalanej biorudy. Przyczynia się to do zmniejszenia emisji gazów cieplarnianych i innych szkodliwych substancji powstajacych podczas spalania biorudy, w porównaniu ze spalaniem węgla. Metoda fitogórnictwa REE jest proekologiczna, sprzyja również zrównoważonemu rozwojowi i gospodarowaniu nieodnawialnymi zasobami Ziemi. Jednym $z$ istotnych minusów fitogórnictwa jest długi okres oczekiwania na zbiór plonów, a ich wydajność zależy od biomasy i szybkości wzrostu roślin. Ograniczeniem moga być również: niewielka biodostępność pierwiastków w glebie, a także konieczność ich występowania w powierzchniowych częściach litosfery (ograniczony zasięg korzeni). Gleby zwykle zanieczyszczone sa różnymi pierwiastkami, które moga zaburzać wzrost roślin. Akumulacja pierwiastków przez rośliny niesie za sobą również ryzyko wprowadzenia zaabsorbowanych metali w łańcuch pokarmowy zwierzat, a dalej ludzi. Jednak przeszkody te należy traktować nie jako wady eliminujace stosowanie fitogórnictwa w praktyce, ale wyzwania, których rozwiazanie będzie stanowić krok ku zrównoważonej gospodarce zasobami. Powszechne wykorzystanie pierwiastków ziem rzadkich w nowoczesnych technologiach obliguje do znalezienia alternatyw ich pozyskiwa- 
nia. Konwencjonalne wydobycie pierwiastków ziem rzadkich w niektórych regionach swiata przyczyniło się do włączenia do globalnego obiegu REE pokłady pierwiastków pochodzenia antropogenicznego. Zanieczyszczenie pierwiastkami ziem rzadkich może wpływać na zdrowie człowieka, dlatego stosowanie technik wykorzystujacych rośliny zdolne do ekstrakcji REE $z$ gleby (fitoremediacja) jest również zasadne. W przypadku fitogórnictwa, część hiperakumulatorów efektywnie pobiera duże ilości REE $z$ gleby, jednak kilka aspektów wymaga jeszcze dodatkowych badań. Pierwszym $z$ nich jest opracowanie efektywnego i taniego pozyskiwania REE $z$ biorudy, a także konieczność przeprowadzania badań i poszukiwania innych gatunków roślin akumulujących REE oraz poznanie szczegółów dotyczacych pobierania, frakcjonowania i akumulacji REE w roślinach. Rozwiazanie tych problemów wydaje się szczególnie istotne nie tylko $z$ punktu widzenia ekonomicznego (obecnie zdominowany rynek przez Chiny), ale także $z$ punktu zrównoważonego gospodarowania nieodnawialnymi zasobami Ziemi.

\section{PODZIĘKOWANIA}

Autorka pragnie serdecznie podziękować Pani Profesor Agnieszce Gałuszce za udzielone wsparcie merytoryczne i korektę tekstu.

$$
\text { Streszczenie }
$$

Komercyjne wydobycie rud metali zwiazane jest zwykle $z$ surowcami mineralnymi zawierającymi znaczne ilości tych pierwiastków i wymaga dużych nakładów finansowych. Tak bogate rudy występuja rzadko, a wzrastajacy popyt na surowce mineralne skutkuje potrzeba znalezienia alternatywnych metod pozyskiwania pierwiastków z rud mniej wzbogaconych. Naprzeciw temu wyzwaniu wychodza dziś nowoczesne metody biotechnologiczne. Część $z$ endemicznych gatunków roślin jest zdolna do gromadzenia w swoich tkankach bardzo wysokich stężeń pierwiastków śladowych i są one znane jako hiperakumulatory. Proces przyswajania pierwiastków z gleby przez hiperakumulatory nazywany jest fitoekstrakcją i może być stosowany $\mathrm{w}$ fitogórnictwie, polegajacym na uprawie roślin na terenach wzbogaconych $\mathrm{w}$ pierwiastki oraz zebraniu i spalaniu biomasy w celu uzyskania cennej ekonomicznie biorudy. Fitogórnictwo jest zgodne ze współczesnymi trendami ekologicznymi i zasadami zrównoważonego rozwoju. Metoda ta jest stosowana od lat 80. ubiegłego stulecia, poczatkowo jedynie w celu pozyskiwania niklu. Obecnie używana jest w szerszym zakresie pierwiastków (m.in. Tl, $\mathrm{Co}, \mathrm{Ag}, \mathrm{Au}$ ), w tym pierwiastków ziem rzadkich (ang. rare earth elements, REE). REE to grupa metali od La do Lu uznawana za kluczową dla rozwoju współczesnej gospodarki. W artykule zaprezentowano najważniejsze aspekty fitogórnictwa REE, jego opłacalność, wady i zalety oraz perspektywy rozwoju w niedalekiej przyszłości.

\section{LITERATURA}

Ali H., Khan E., SAJAD M. A., 2013. Phytoremediation of heavy metals - Concepts and applications. Chemosphere 91, 869-881.
BHargava A., CARMona F. F., BhargaVa M., SRIVASTAVA S., 2012. Approaches for enhanced phytoextraction of heavy metals. J. Environ. Manage. 105, 103-120.

BOLAN N., KUNHIKRISHNAN A., THANGARAJAN R., Kumpiene J., PARK J., MAKINO T., KIRKHAM M. B., SCHECKEL K., 2014. Remediation of heavy metal(loid)s contaminated soils. To mobilize or to immobilize? J. Hazard. Mat. 266, 141-166.

BROOKS R. R., LEE J., REEVES R. D., JAFFRÉ T., 1977. Detection of nickeliferous rocks by analysis of herbarium specimens of indicator plants. J. Geochem. Explor. 7, 49-57.

BRoOKS R. R., CHAMBERS M. F., NiCKS L. J., RoBINSON B. H., 1998. Phytomining. Trends Plant Sci. 3, 359-362.

BRown P. H., RATHJEN A. H., Graham R. D., TRIBE D. E., 1990. Rare earth elements in biological systems. [W]: Handbook on the Physics and Chemistry of Rare Earths. vol.13. GSCHNEIDNER K. A. JR., EYRING L. (red.). Elsevier Sciences Publisher B. V., New York, 423-453.

Clemens S., 2001. Developing tools for phytoremediation: towards a molecular understanding of plant metal tolerance and accumulation. Int. J. Occupat. Med. Environ. Health 14, 235-239.

CoOK N. J., CiOBANU C. L., O'RIElly D., WilsoN R., DAS K., WADE B., 2013. Mineral chemistry of Rare Earth Element (REE) mineralization, Browns Ranges, Western Australia. Lithos 172-173, 192-213.

EAPEN S., D'SouZA S. F., 2005. Prospects of genetic engineering of plants for phytoremediation of toxic metals. Biotechnol. Adv. 23, 97114.

Fedele L., Plant J. A., De Vivo B., Lima A., 2008. The rare earth element distribution over Europe: geogenic and anthropogenic sources. Geochem. Explor. Environ. Anal. A 8, 3-18.

GAŁUSZKA A., 2005. Wykorzystanie mikroorganizmów i roślin do pozyskiwania metali. Przegl. Geol. 53, 858-862.

JAFFRÉ T., BROOKS R. R., LEE J., REEVES R. D., 1976. Sebertia acuminata: a nickel-accumulating plant from New Caledonia. Science 193, 579-580.

KRZCIUK K., GAŁUSZKA A., 2015. Prospecting for hyperaccumulators of trace elements: a review. Crit. Rev. Biotechnol. 35, 522-532.

LASAT M. M., 2002. Phytoextraction of toxic metals: a review of biological mechanisms. J. Environ. Qual. 31, 109-120.

Laubie B., ChOur Z., GuO M. N., Liu C., Yuan M., LIU W. S., MOREL J. L., TANG Y. T., SIMONNOT M-P. R. O., MUHR L., 2016. Rare Earth Element (REE) recovery from Dicranopteris dichotoma. 9th Sino-French workshop on soil pollution and remediation: reclamation and valorization of mine sites. Guangzhou (China), $31^{\text {st }}$ October $-3^{\text {rd }}$ November.

Liu C., Yuan M., LiU W.-S., GuO M.-N., HuOT H., Tang Y.-T., Laubie B., Simonnot M.-O., MOREL J. L., QIU R.-L., 2018. Element case studies: rare earth elements. [W]: Agromining: farming for metals, mineral resource reviews. VAN DER ENT A., ECHEVARRIA G., BAKER A. J. M., MOREL J. L. (red.). Springer International Publishing AG, Cham, 297-308.

MARKERT B., 1992. Establishing of 'reference plant' for inorganic characterization of different plant species by chemical fingerprinting. Water Air Soil Pollut. 64, 533-538.

OzAKI T., ENOMOTO S., Minai Y., AmBE S., MAKIDE Y., 2000. A survey of trace elements in pteridophytes. Biol. Trace Elem. Res. 74, 259-273. 
Petrosino P., SADEghi M., Albanese S., ANDERSSON M., LIMA A., DE VIVO B., 2013. REE contents in solid sample media and stream water from different geological contexts: Comparison between Italy and Sweden. J. Geochem. Explor. 133, 176-201.

REEVES R. D., 1992. Hyperaccumulation of nickel by serpentine plants. [W]: The Vegetation of Ultramafic (Serpentine) Soils. BAKER A. J. M., PROCTOR J., REEVES R. D. (red.). Intercept Ltd., Andover, 253-277.

SHAH K., NONGKYNRIH J. M., 2007. Metal hyperaccumulation and bioremediation. Biol. Plant. 51, 618-634.

Sheoran V., Sheoran A., Poonia P., 2009. Phy tomining: a review. Minerals Engin. 22, 10071019.

Thomas P. J., Carpenter D., Boutin C., Allison J. E., 2014. Rare earth elements (REEs): Effects on germination and growth of selected crop and native plant species. Chemosphere 96, 57-66.

THOMAS W. A., 2011. Accumulation of rare earths and circulation of cerium by mockernut hickory trees. Canad. J. Bot. 53, 1159-1165.

VAN Der EnT A., BAKer A. J. M., ReEves R. D., POLlARD A. J., SCHAT H., 2013. Hyperaccumulators of metal and metalloid trace elements: facts and fiction. Plant Soil 362, 319-334.

WANG Y., YAN A., DAI J, WANG N. N., WU D., 2012. Accumulation and tolerance characteristics of cadmium in Chlorophytum comosum: a popular ornamental plant and potential $\mathrm{Cd}$ hyperaccumulator. Environ. Monitor. Assess. 184, 929-937.

XUE Y., 2009. Studies of the hyperaccumulation ability of Pronephrium simplex and Pronephrium triphyllum to rare earth elements and their binding peptides. Xiamen University, BSc Thesis, Xiamen.

Yang X., Feng Y., He Z., Stoffella P. J., 2005. Molecular mechanisms of heavy metal hyperaccumulation and phytoremediation. J. Trace Elem. Med. Biol. 18, 339-353.

ZHANG C., LI Q., ZHANG M., ZHANG N., LI M., 2013. Effects of rare earth elements on growth and metabolism of medicinal plants. Acta Pharmaceutica Sinica B 3, 20-24.

Zhang H., Feng J., Zhu W. F., LIU C. Q., Xu S. Q., SHAO P. P., WU D.S., YANG W. J., GU J. H., 2000. Chronic toxicity of rare earth elements on human beings. Biol. Trace Elem. Res. 73, 1-17.

Zhang X., Houzelot V., Bani A., Morel J. L., ECHEVARRIA G., SIMONNOT M.-O., 2014. Selection and combustion of Ni-hyperaccumulators for the phytomining process. Int. J. Phytoremed. 16, 1058-1072.

ZHU W., XU S., ZHANG H., FENG J., 1996. Investigation on the intelligence quotient of children in the areas with high REE background (I) - REE bioeffects in the REE-high areas of southern Jiangxi Province. Chin. Sci. Bull. 41, 1977-1981.

KOSMOS Vol. 68, 3, 443-449, 2019

KARINA KRZCIUK

Geochemistry and the Environment Division, nstitute of Chemistry, Jan Kochanowski University in Kielce, 15G Świętokrzyska St., 25406 Kielce, E-mail: karina.krzciuk@ujk.edu.pl

PHYTOMINING OF RARE EARTH ELEMENTS (REE) AS A METHOD OF SUSTAINABLE MANAGEMENT OF NONRENEWABLE RESOURCES

\section{Summary}

Commercial mining of elements is usually based on very enriched ores and requires large financial outlays. Ores revealing high concentrations of metals and non-metals rarely occur in nature. On the other hand, the suband low- grade ore bodies are localized in many parts of world, but their use in conventional mining is not profitable. An increasing demand for mineral resources imposed the need for a search of new mining methods that could employ sub- and low-grade ores. Innovative biotechnology techniques could provide the solution to this problem. Some of the endemic plant species are able to accumulate extremely high concentrations of elements and are known as hyperaccumulators. The process of uptake elements from the soil by hyperaccumulators is called phytoextraction and can be used in phytomining. Phytomining method is based on planting the hyperaccumulator crops over a low and sub-grade ores or mineralized soils, harvesting and burning yields to produce commercial bio-ore. Phytomining is known as compatible with contemporary green trends and sustainable development. This method has been used since the 80 s of the last century, initially, it was only applied to recover nickel from burned plant biomass. Currently is used for a wider range of elements (e.g. Tl, Co, Ag, Au), as well as for the rare earth elements (REE). REE are metals from La to Lu recognized as crucial for the development of modern economy. This article presents the most important aspects of phytomining of REE, its profitability, the advantages and disadvantages of the method and its development prospects in the near future. 